\title{
Tutor perception on personal and institutional preparedness for online teaching-learning during the COVID-19 crisis: The case of Ghanaian Colleges of Education
}

\author{
Alexander Obiri Gyampoh ${ }^{1}$, Henry Kwao Ayitey ${ }^{1}$, Charles Fosu-Ayarkwah ${ }^{1}$, Seth Akyea Ntow ${ }^{1}$, \\ Joseph Akossah ${ }^{1}$, Miracule Gavor ${ }^{2}$ and Dimitrios Vlachopoulos ${ }^{3 *}$ \\ ${ }^{1}$ Kibi Presbyterian College of Education, Kibi, Ghana. \\ ${ }^{2}$ Transforming Teacher Education and Learning, Ghana. \\ ${ }^{3}$ Amsterdam University of Applied Sciences, Netherlands. \\ Accepted 2 July, 2020
}

\begin{abstract}
This paper looks at Ghanaian Colleges of Education tutors' perception on the personal and institutional preparedness for online teaching-learning during the COVID-19 crisis. The study selected 24 tutors from 9 Colleges of Education (CoEs) in the Eastern and Greater Accra Regions. 7 CoEs are in Eastern while 2 are in Greater Accra. Using the convenience sampling technique, 24 tutors were selected as the accessible population. The research design used was the qualitative with a semi-structured interview conducted over the telephone because of social distancing. The data collected was analysed manually. The results indicate that only $33.3 \%$ of the respondents could teach confidently online, while $66.7 \%$ needed more training to confidently deliver lessons online. Furthermore, none of the 9 colleges had policies on online teaching even though each college had at least 16 policies regarding the good governance of the colleges. It is therefore recommended that tutors of CoEs should be given support in ICT and online skills and competencies through continuous training.
\end{abstract}

Keywords: COVID-19, emergency remote teaching, Colleges of Education, teachers' perceptions.

${ }^{*}$ Corresponding author. E-mail: d.v.vlachopoulos@hva.nl. Tel: +3161140 5030.

\section{INTRODUCTION}

Coronavirus disease, which is also known as COVID-19, was believed to have first been identified in Wuhan, China in December, 2019. The devastating effect of COVID-19 has compelled the World Health Organization to declare it a pandemic (WHO, 2020). Ghana recorded its first two cases of infection on $12^{\text {th }}$ March, 2020 as reported by the Health Minister after test results were released from Noguchi Memorial Institute for Medical Research in Accra (Dogbevi, 2020). Current statistics in Ghana, as at 9th June, 2020, stands at 9,910 confirmed cases, 3,635 recoveries, and 48 deaths (Ghana Health Service, 2020).

In order to prevent new infections and also to minimize the rate of spread of the disease, schools in Ghana were closed down on $16^{\text {th }}$ March, 2020. There is therefore the need to address the educational challenges in a situation where our school children and students are at home due to the fact that schools have been closed down because of the rampaging effect of the disease. In tertiary education, academic and research activities have basically come to a halt. As of April 8, universities and other tertiary education institutions were closed in 175 countries and communities, and over 220 million postsecondary students have had their studies ended or significantly disrupted due to COVID-19 (World Bank, 2020). There is no doubt that the global closure of educational institutions has brought about interruptions in the learning of students as asserted by Burgess and 
Sievertsen (2020).

The threat of COVID-19 has obliged colleges and universities to make crucial decisions on how to keep offering education while keeping their community (management members, staff and students) safe from a public health emergency that is impacting the whole world. Only few institutions decided to cancel their educational activity and accept the devastating consequences at both financial and academic level. The majority of institutions shifted their education delivery from conventional (face-to-face) learning to online learning, which can enable a more flexible approach to teaching and learning (Vlachopoulos, 2020). This "use of fully remote teaching solutions for instruction or education that would otherwise be delivered face-to-face or as blended or hybrid courses and that will return to that format once the crisis or emergency has abated" (Hodges et al., 2020) is called emergency remote teaching. Despite the fact that there is agreement of the importance and value of continuing the educational offer during the COVID-19 crisis, not all institutions are fully prepared and equipped to implement effective emergency remote teaching.

\section{Online education and emergency remote teaching}

We can find several definitions of online learning in current literature, fact that demonstrates that it is an evolving concept. Sangrà et al. (2012: 152), define online learning as "an approach to teaching and learning, representing all or part of the educational model applied, that is based on the use of electronic media and devices as tools for improving access to training, communication and interaction and that facilitates the adoption of new ways of understanding and developing learning". Sharma and Kitchens (2004) had previously defined online learning as the use of web-based training facilities, such as virtual universities and classrooms that allow digital collaboration and technology-assisted distance learning.

Reflecting on these definitions, we can conveniently say that online learning involves the giving of learning instructions through the internet with the use of electronic devices. For online learning to be effective, both the instructor and the learner must have good internet services and adequate electronic devices. Also, despite the variety of definitions, there is an agreement that online learning plays a crucial role in the educational growth of many nations and it offers the needed opportunities to developed nations in order to enhance their educational development.

\section{The situation in Ghanaian Colleges of Education}

Colleges of Education (CoEs) in Ghana were supposed to have reopened on the $16^{\text {th }}$ of March, 2020, for the second semester of the 2019/2020 academic year.
However, due to the COVID-19 crisis, it was not possible. In order to complete the academic calendar, authorities have put a lot of measures in place. One of such measures is emergency remote learning or online teaching and learning.

In response to COVID-19 emergency remote teaching, National Council for Tertiary Education, NCTE, in collaboration with Transforming Teaching and Learning in Ghana, T-TEL, put in place a Virtual Learning Taskforce for Teacher Education. The Taskforce included all five mentoring universities, key stakeholders such as the Principals of Colleges of Education (through PRINCOF), College of Education tutors and non-teaching staff, and student teachers (through their respective unions) (Salifu and Todd, 2020). According to Salifu and Todd, the Taskforce meets regularly to ensure that teacher education continues through virtual and online learning until such a point as institutions can re-open.

The universities have also extended their virtual learning environment to student teachers in their affiliated Colleges of Education. The Universities have also activated their Learning Management Systems (LMS) so that students can fully participate in the emergency remote teaching and learning. Current data available from the CoE affiliated universities indicates 85 to $90 \%$ registration of students in virtual learning portals (Salifu and Todd, 2020).

Furthermore, most CoEs have been doing some level of emergency remote teaching using social media platforms such as WhatsApp and Telegram during the COVID-19 crisis. Additionally, in an attempt to ensure gender equity and social inclusion, all colleges and universities have been tasked to design their portals for teaching and learning to be gender sensitive, user friendly, and also be accessible no matter the disability of the user.

The questions to be asked therefore would be whether Colleges of Education in Ghana have online resources, whether tutors in the colleges have the needed skills, competencies, and knowledge to do emergency remote teaching; and whether these colleges have online learning policies at all to provide guidelines for that mode of teaching and learning.

This article looks at Ghanaian Colleges of Education tutors' perceptions on the response of the education sector to COVID-19 crisis. The paper also looks at the preparedness of the CoEs to take up this challenge of emergency remote teaching or online teaching and learning by looking at three critical themes: Skills, competencies and knowledge that tutors need for successful online teaching; Policies related to online learning; and resources needed for effective online teaching.

\section{Research questions}

The following questions guide the research: 
1. What kind of professional skills, competencies, and knowledge do Ghanaian Colleges of Education tutors have in order to do teaching, learning, and assessment online?

2. What online policies do Ghanaian Colleges of Education have?

3. What kind of online resources do Ghanaian Colleges of Education tutors have to deliver online teaching and learning?

Tutors in the colleges have risen to the challenge, but the question remains as to whether the responses given are enough or not.

\section{METHODOLOGY}

\section{Data collection}

The researchers used semi-structured interviews, which constituted the main phase of data collection of a phenomenology qualitative methodology research, to investigate tutor perception on personal and institutional preparedness for online teaching and learning during the COVID-19 crisis. This methodology was adapted because most of the researchers are also tutors of the colleges; hence they experience the same issues that the respondents faced. The interview guide was structured taking into consideration the main themes of tutors' professional skills, competencies and knowledge, policies, and online resources. Tutors from the Colleges of Education in the Eastern and Greater Accra Regions of Ghana were interviewed over the telephone due to social distancing, which is one of the COVID-19 protocols. Permission was sought from the respondents before a recording of the interviews was done. Apart from that they were assured that their participation was anonymous and voluntary. This was done to satisfy ethical conditions. In all, the researchers interviewed a total of 24 tutors, comprising 10 females and 14 males from 9 colleges out of 46 public Colleges of Education in Ghana. This therefore formed the sample. The convenience sampling technique was used to select the sample for the study, because of the lock-down of Colleges of Education.

\section{Data analysis}

For this qualitative descriptive research, the data analysis is done manually, without the use of any data analysis software. The analysis of qualitative data is a very enriching process because themes and concepts are discovered during the data collection process (Fernández Nuñez, 2006). As data analysis progresses, these themes and concepts are woven into a broader explanation of theoretical or practical importance (Rubin and Rubin, 1995). This analysis must be systematic and must follow a sequence and an order (Álvarez-Gayou,
2005).

Taking into consideration all the above, the steps followed for data analysis in this study are:

- Obtain information, through semi-structured interviews.

- Capture and order the information, through an electronic register.

- Codify the information, grouping the information obtained into categories that concentrate the ideas and similar themes discovered by the main researcher.

- Integrate the information, relating the categories obtained in the previous phase to each other and to the theoretical foundations of the study.

Taking into consideration the three research questions and the answers of the 24 participants, we identify three main themes: a) Skills, competencies and knowledge that tutors need for successful online teaching, b) Policies related to online learning and c) resources needed for effective online teaching. Table 1 presents the subthemes identified for each theme.

\section{Description of respondents}

The average age of the respondents is 40 years, with their teaching experience spanning between 9 and 34 years. The average number of teaching years of the respondents can be pegged at 22 years. The course level they are teaching is tertiary; therefore all of them have 1st and 2 nd degrees.

\section{Description of interview sessions}

All the respondents availed themselves for the interviews without any compulsion after the objectives of the study were announced to them. Except for 1 tutor who pleaded for a re-schedule of the meeting to a later time, all 23 tutors granted interviews to the researchers immediately they were informed about the study. The interviews conducted were from 8 a.m. to 2 p.m. each day. Each interview lasted between 15 and 20 minutes per interview. The researchers therefore took 1 week to conduct the interviews.

The respondents were ready to give candid responses, because to them the whole world is in a new normal hence something drastic should be done if education in the Colleges of Education in Ghana is to catch up with the rest of the world. They therefore suggested that online teaching should go hand in hand with the traditional teaching in our schools. $25 \%$ of the respondents wanted to know whether the respondents would let the authorities know of their findings. They were full of delight when the researchers wanted to know of the kind of support they needed. In general they are aware of the measures taken and implemented by their respective Colleges in response to the COVID-19 crisis. 
Table 1. Themes identified during data analysis.

\begin{tabular}{lll}
\hline Skills, competencies and knowledge needed & Policies & Resources \\
\hline Technical skills & Financial policies & Technical (devices, hardware) \\
Pedagogical skills & HR policies & Human \\
Soft skills and managerial skills & Teaching and learning policies & Financial \\
& Acceptable use policy & \\
& Code of conduct & \\
\hline
\end{tabular}

\section{Skills, competencies and knowledge needed}

\section{Technical skills}

Only $33.3 \%$ responded that they had technical skills to do online teaching in that they can prepare documents in word processing, spreadsheet, power point and search engine. Example is seen below:

STICKER: I have attended numerous training and seminars on office suite in education therefore I have the needed skills, competencies and knowledge to do online teaching. Again, the University-led online Certificate in Design, Teaching and Learning course delivered by the Amsterdam University of Applied Sciences, for CoE tutors have also positioned me very well.

In contrasts, majority of the respondents (66.4\%) had little competence, skills and knowledge needed to teach online. Some of the answers given have been captured as follows:

PASSWORD: I can just record my voice and post it on WhatsApp group for my students to listen to it. I do not know how to even use power point in teaching. I have therefore sought the assistance of our online co-ordinator to enable me acquire the skills.

MUNGO: I was born before computer (BBC) so it is difficult for me to even use ATM card to withdraw cash hence I do not have any technical skills to help me teach online.

\section{Pedagogical skills}

$42.9 \%$ of the respondents use the blended approach whereby materials are sent to the students in advance before discussions are done online. This takes into account the learning environment of the students as at now. A comment from one of respondents is captured below:

FANTA: I usually send a notice to my students in their WhatsApp group, agreeing with them on when to discuss text and videos sent to their google classroom. Again, we meet on Zoom platform to do live interactions for explanations and answering of their questions.

Also, $57.1 \%$ of those interviewed were not able to state the kind of pedagogical skills they normally use during their online interaction with their students. Below is a comment:

WIRE: I only record audios of my lessons and post in the WhatsApp platform for my learners to access.

\section{Soft skills and managerial skills}

Even though tutors have been communicating and managing their learning environments very well in the traditional face-to-face classrooms, not much can be said about such skills during online teaching as $70 \%$ of the respondents averred that they found it very difficult to communicate and manage their online sessions with their students especially when using Zoom platforms. Below is a response from one interviewee:

TUGGY: I usually get upset when background noise from students interrupts with my lessons and even when they put on their videos and begin to complain about poor internet connectivity.

However, the remaining $30 \%$ believe that they effectively communicate well to their students during online sessions and have absolute control of students when there are any interruptions when they use zoom platform. Below is an extract:

EFFIE: I configure my Zoom meetings with restrictions and send the meeting links to them on WhatsApp, so students only join with camera and audio already off, and can only speak when given access.

\section{Policies}

All the respondents had confirmed the availability of the 
various policies at the CoEs including: Acceptable use, Financial management, Code of conduct, and Assessment policies. These policies are to help in the governance of the CoEs. However, they could not mention some of the characteristics or the issues that such policies seek to address. All the respondents said there was no policy on online teaching and learning in the colleges, but they will recommend to their management to draft one because it is useful. Below are extracts:

CRISTAL: Hmmmmmm, these policies again. Me I don't know the names of the policies we have in my college, but l'm told we have more than sixteen policies.

SPEC: I do not have copies of the policies and besides I was not part of those who drafted them so I cannot speak to it.

FIRE: There are no policies on online teaching and learning.

JACK: The policy will make us ready for such a precarious situation.

SHANKS: Online policy will give us the opportunity to engage learners all the time even during vacation."

\section{Online resources}

\section{Technical resource (devices, hardware)}

Almost all the respondents mentioned some devices and hardware as resources. However, only $40 \%$ said they have their personal laptops, smart phones, and external hard drive. The remaining $60 \%$ said they only have smart phones. Below are some of their comments:

SANTO: I always teach with my laptop, projector and at times I send my students links to watch useful videos in UTUBE, so when it comes to such resources, l'm full prepared.

SHANE: Hmmmm, it is the duty of the employer to provide resources for me to work effectively. I have my smart phone to support so when it comes to laptop, the college must provide.

\section{Human resources}

In seeking for an answer to whether there were professionals (experts) who were very efficient to support tutors to carry out effective online lesson delivery, below are some answers:

YAAYO: Yes, our college has a virtual learning coordinator and two ICT tutors who provide useful support to us. They had training with us on how to use Zoom, Telegram and Google classroom. A special WhatsApp platform has also been created to help address some of our concerns.

MIMI: In my college, we have a virtual learning co-ordinator who does report activities to college management. Though we have ICT tutors they are also confused like every one of us when it comes to online teaching.

\section{Financial resources}

From the analysis, $83 \%$ of the respondents said that financial resources are urgently needed to make online successfully while $17 \%$ said they have the needed financial resources. Below are some comments:

RAW: In my college, we do not have internet connectivity, laptops, printers and projectors and therefore we need funds to purchase ICT resources to be able to teach online.

BEAUTY: My college need funds to buy laptop and other ICT tools for us so that we can practice with it, become experts and deliver our lessons both online and traditional very well.

When we analyzed all these 24 interviews, we found that as far as the first research question "What kind of professional skills, competencies, and knowledge do Ghanaian Colleges of Education tutors have in order to do teaching, learning, and assessment online?" was concerned, all the respondents in the colleges have taught between 9 years and 34 years, but have little knowledge in ICT, and the skill to do online teaching. Many of the tutors acquired the skills, competence and knowledge from the university-led online Certificate in Design, Teaching and Learning course delivered by the Amsterdam University of Applied Sciences, which over 1,600 tutors took advantage of.

To be able to teach effectively online, tutors need certain competencies. Salmon (2003) cited in Albrahim (2020) describes and groups the qualities or competencies into five categories, namely: understanding the online process, technical skills, online communication skills, content expertise, and personal characteristics. Teaching online during this COVID pandemic can be termed as a response to an emergency remote situation. Nobody knows how long the pandemic will be with us. If the pandemic should end within a short period, there will be the need to go back to the traditional face-to-face mode of teaching and learning. The researchers are proposing that the curriculum framework in teacher education should be reviewed to include online teaching as one of the modes of teaching and learning. Hence, tutors should be given more training in online teaching.

Actually, The Digital Society, The Amsterdam 
University of Applied Sciences came at the right time to organise the 8-module course for online teaching for most of the tutors in the colleges. Some colleges are also in consultation with some private universities, which are into online education, to train their tutors on online learning. All this is being done to make tutors acquire the necessary skills, competence, and the knowledge to enable them rise to the challenge of teaching online.

In answering research question 2, 'What online policies do Ghanaian Colleges of Education have?', the researchers found out that all the colleges have at least 16 policies, namely: Financial policy, Assessment policy, Acceptable use, Teaching and learning policy, code of conduct, and Student engagement, among others; However, there is no policy on online teaching. It is also interesting to note that none of the respondents was able to tell the interviewers the highlights or characteristics of the policies that their colleges have. They however said they will suggest to management to have an online policy in their colleges as it will benefit the college in various ways.

In answering research question 3, "What kind of online resources do Ghanaian Colleges of Education tutors have to deliver online teaching and learning?", we found that some of the respondents have their personal laptops, smartphones, USB pen drives, external hardisks, and modems. In the area of human resource, some respondents said their colleges have appointed staff who are have ICT skills to be virtual learning co-ordinators. They also said their colleges needed funds to procure more laptops, and smartphones for the staff and students. Furthermore, they said they needed strong internet connectivity in their colleges.

\section{DISCUSSION}

\section{Challenges with online teaching and learning}

Many experienced teachers who use face-to-face mode find themselves as novices or beginners when first teaching online (McQuiggan, 2007). When teachers switch from traditional classroom or face-to-face teaching to online teaching in a virtual classroom, they see the teaching experience entirely different. It takes time for them to become used to the online teaching.

Another challenge in online teaching has do with technical difficulties on the part of both teachers and the students. A lot of teachers do not have the technical training to be able to teach online, coupled with unreliable internet connectivity. Some of them are not conversant with the use of Google Drives and other Applications. A lot of students even though technologically savvy, are not proficient in using unfamiliar software or in using it in a responsible manner.

Teachers have to prepare and plan materials for online courses. This task of generating new materials from the traditional face-to-face classes to an online mode is a challenge that teachers face ( $\mathrm{Li}$ and Irby, 2008). KyeiBlankson and Keengwe (2011) are of the view that proper training and support have not been provided to instructors who are transforming course content from the traditional face-to-face to online mode.

Another major challenge with online teaching is the changing role of the instructor (Berge and Collins, 1996; Coppola et al., 2001; Syverson and Slatin, 2010). Berge (1998) identified four different roles for online instructors. These are pedagogical, social, managerial, and technical responsibilities.

Finally, Behera (2013) lists lack of equipment as a challenge in online teaching. Computers and their accessories, smart phones and other ICT tools needed for online teaching are a challenge in online learning and teaching.

\section{Access to resources}

In the Colleges of Education, there are challenges with resources for online teaching and learning as it is with all the other tertiary institutions. A survey conducted on "ICT Capacity in public Colleges of Education", which was commissioned and managed by the National Council for Tertiary Education (NCTE) and implemented by Consumer Insights Consult (CiC) with support from Transforming Teaching and Learning in Ghana (T-TEL), which is funded by UKaid T-TEL (2017), concludes that, "CoEs are on a journey towards the full integration of ICT in both the management and delivery of teacher education but that their progress is uneven. Indeed, ICT capacity in most Colleges of Education falls far short of what is required to prepare pre-service teachers to deliver a modern education in schools.' In addition the report states that "Only 8 Colleges (20\%) out of 40 CoEs used for the study, have appointed non-teaching staff members to be responsible for managing the ICT system (ICT technician), an essential staff post for any institution wishing to have a functioning ICT infrastructure serving hundreds of users" (Cambridge Education, 2017).

The survey recommended that "a CoE Sector Strategy for Integration of ICT in Education be developed through a partnership of CoE stakeholders led by PRINCOF." The report went further to state that, "The strategy could consider shared concerns such as access to affordable internet connectivity, open access resources for colleges, integrating ICT in education", among others.

From the survey, it can be concluded that Colleges of Education in Ghana are not fully prepared to use online learning and therefore an aggressive resource development must be pursued in terms of manpower and infrastructure.

To help in addressing some of the challenges, Salifu and Todd (2020) posit that Transforming Teaching and Learning in Ghana (T-TEL) in collaboration with National 
Council for Tertiary Education (NCTE) are supporting tutors to adapt their lessons and teaching so that they take account of the specific demands of online learning, by enrolling over 1,600 tutors on university-led courses and regular virtual lesson observation. This course was to build tutor capacity on the essential elements of online teaching. Clearly, it can be seen that steps are being taken to help colleges in their response to COVID-19. However, other issues such as assessment, supported teaching in schools for B.Ed students, and off-campus teaching practicum for the last batch of diploma students still hang in the balance. There is therefore the need to review current regulatory frameworks and policies of teacher education, rethink and redesign teaching and learning in our colleges.

\section{Policies at Colleges of Education}

A policy statement is an organisational-level document that prescribes acceptable methods of behaviours. Essentially, a policy is simply the way things are done within an organisation. Policies are primarily intended to set directions. Polices are meant to ensure that statutory requirements are complied with.

However, there are no policies in the Colleges of Education on emergency remote teaching to serve as a guide, perhaps nobody anticipated this

Colleges of Education have been guided by T-TEL to draft a number of policies. The following are the policies that the colleges formulated: Gender and Inclusion, Financial Management, Health and Safety, Teaching and Learning, Assessment, Quality Assurance, Admissions, Appointments and Promotions, Staff Training and Development, Staff and Students Discipline, Conflict Management, Sexual Harassment, Acceptable use - ICT and Library, Research, and Estate Development (T-TEL, 2016).

One can notice from the above that even though colleges have Acceptable use - ICT and Library, among other policies, none of these policies was clear on the use of online teaching and learning.

The Ministry of Education and policy makers should therefore create a framework for online policies for each level of education, especially Colleges of Education. This policy must focus on the needed strategies or methodologies and the intended outcomes. Of course, it must be based on experiences and good practices, with the stakeholders in mind.

From the findings of the study, we realised that the response given by the tutors of the Ghanaian Colleges of Education to the emergency remote teaching is quite good, as many of the tutors are acquiring the skills, competencies and knowledge to enable them be successful. A case in point is their training they received from The Digital Society where about 1600 tutors benefited (Salifu and Todd, 2020). Some private
Universities which make use of online learning are also training the Colleges of Education tutors to acquire the needed skills on online teaching. Our findings also brought to the fore the need for the colleges to provide a budget line to support the acquisition of ICT tools (hardware) and the training of staff to enable them use ICT resources with dexterity. Furthermore, there is the need for the colleges to have a strong internet.

We also advocate the use of blended learning in our colleges during the post COVID-19 period. This blended learning can be achieved when part or some aspect of course outlines are taught through online learning and the other part taught using the traditional face-to-face mode. This should be part of a framework for teacher education.

To add to the above, the researchers propose that supported teaching in schools, as well as supported teaching in schools teaching practicum can also be partly done online, where the student-teacher will upload videos of his or her teaching to be viewed by a team of supervisors who will give feedback to the student teacher. The mentors and lead mentors' roles, such as reflective activities conducted with student teachers, can also be viewed on student-uploaded videos, supervisors, without the physical presence of the supervisors on the field. COVID-19 affords everybody the opportunity to practically think outside the box for the purpose of moving teacher education forward.

This study is a baseline on which further studies can be conducted. The study was limited to the Colleges of Education in the Eastern and Greater-Accra Regions. Due to COVID-19 protocols, a face-to-face interview was not possible, so the researchers used the telephone. Future studies can therefore focus on other regions using other data collection tools to confirm the findings. Future studies can also focus on the level of ICT skills of student teachers in the Colleges of Education.

\section{REFERENCES}

Álvarez-Gayou, J. L. (2005). Cómo hacer investigación cualitativa. Fundamentos y metodología. México: Paidós.

Behera, S. K. (2013). E- and m-learning: A comparative study. International Journal on New Trends in Education and Their Implications, 4(3): 65-78.

Berge, Z. L. (1998). Barriers to online teaching in post-secondary institutions: Can policy changes fix it? Online Journal of Distance Learning Administration, 1(2).

Berge, Z. L., and Collins, M. (1996). Facilitating interaction in computer mediated online courses. FSU/AECT Distance education conference. Tallahassee, FL.

Burgess, S., and Sievertsen, H. H. (2020). Schools, skills, and learning: The impact of COVID-19 on education. Retrieved from https://voxeu.org/article/impact-covid-19-education

Cambridge Education (2017). A Survey of ICT Capacity in Ghana's Public Colleges of Education. Retrieved from http://www.ttel.org/files/docs/Learning\%20Hub/Research\%20and\%20 evidence\% 20-\%20teacher\%20education\%20in\%20Ghana/ICT\%20Survey\%20 Report\%20.pdf.

Coppola, N. W., Hiltz, S. R., and Rotter, N. (2001). Becoming a virtual professor: Pedagogical roles and ALN. System Sciences, 2001. 
Proceedings of the 34th Annual Hawaii International Conference. Hawaii.

Dogbevi, E. K. (2020). Ghana confirms first COVID-19 cases. Retrieved from https://www.ghanabusinessnews.com/2020/03/12/ ghana-confirms-first-covid-19-cases/.

Fernández Núñez, L. (2006). Com analizar dades qualitatives? Barcelona: Universitat de Barcelona. Institut de Ciències de l'Educació.

Ghana Health Service (2020). COVID-19, Ghana's outbreak response management updates. Retrieved from https://www.ghanahealth service.org/covid19/.

Hodges, C., Moore, S., Lockee, B., Trust, T., and Bond, A. (2020). The difference between emergency remote teaching and online learning. EDUCAUSE Review, 3. Retrieved from https://er.educause.edu /articles/2020/3/the-difference-between-emergency-remote-teachingandonline-learning.

Kyei-Blankson, L., and Keengwe, J. (2011). Faculty-faculty interactions in online learning environments. International Journal of Information and Communication Technology Education, 7: 25-33.

Li, C., and Irby, B. (2008). An overview of online education: Attractiveness, benefits, challenges, concerns, and recommendations. College Student Journal, 42: 449-458.

McQuiggan, C. A. (2007). The role of faculty development in online teaching's potential to question teaching beliefs and assumptions. Online Journal of Distance Learning Administration, 10(3). Retrieved from https://eric.ed.gov/?id=EJ1065614.

Rubin, H. J., and Rubin, I. S. (1995). Qualitative interviewing. The art of hearing data. Thousand Oaks, CA: Sage.

Salifu, M., and Todd, R. (2020). Ghana's Teacher Education System and Responding to COVID-19. Retrieved from https://www.ttel.org/news-view/ghanas-teacher-education-system-and-respondingto-covid-19.

Sangrà, A., Vlachopoulos, D., and Cabrera, N. (2012). Building an inclusive definition for e-learning: an approach to its conceptual framework. The International Review of research in Open and Distance Learning, 13(2): 145-159.
Sharma, S. K, and Kitchens, F. L. (2004). Web services architecture for m-learning. International Journal of Mobile Communications, 2(1): 203-216.

Syverson, M. A., and Slatin, J. (2010). Evaluating learning in virtual environment. Retrieved from http://www.learningrecord.org/caeti.html

Vlachopoulos, D. (2020). COVID-19: Threat or opportunity for online education. Higher Learning Research Communications, 10(1).

WHO (2020). Director-General's opening remarks at the Mission briefing on COVID-19. Retrieved from https://www.who.int/dg/ speeches/detail/who-director-general-s-opening-remarks-at-themission-briefing-on-covid-19.

Citation: Gyampoh, A. O., Ayitey, H. K., Fosu-Ayarkwah, C., Ntow, S. A., Akossah, J., Gavor, M., and Vlachopoulos, D. (2020). Tutor perception on personal and institutional preparedness for online teaching-learning during the COVID-19 crisis: The case of Ghanaian Colleges of Education. African Educational Research Journal, 8(3): 511-518. 